\title{
Quality and Shelf Life of White Shrimp (Litopenaeus vannamei) Processed with High-Pressure Carbon Dioxide (HPCD) at Subcritical and Supercritical States
}

\author{
Maria Erna Kustyawati $\left(\mathbb{D},{ }^{1}\right.$ Filli Pratama, ${ }^{2}$ Samsul Rizal ${ }^{D},{ }^{1}$ Esa Ghanim Fadhallah $\left(\mathbb{D},{ }^{1}\right.$ \\ and Abdullah Aman Damai $\mathbb{D}^{1}$ \\ ${ }^{1}$ Department of Agriculture Product Technology, University of Lampung, Bandar Lampung, Indonesia \\ ${ }^{2}$ Department of Agriculture Technology, University of Sriwijaya, Palembang, Indonesia \\ Correspondence should be addressed to Maria Erna Kustyawati; maria.erna@fp.unila.ac.id
}

Received 12 November 2020; Revised 10 March 2021; Accepted 21 June 2021; Published 30 June 2021

Academic Editor: Flora V. Romeo

Copyright (C) 2021 Maria Erna Kustyawati et al. This is an open access article distributed under the Creative Commons Attribution License, which permits unrestricted use, distribution, and reproduction in any medium, provided the original work is properly cited.

\begin{abstract}
Phase changes of carbon dioxide (supercritical or subcritical) depend on its proximity to a pressure of $7.35 \mathrm{MPa}$ and temperature of $31.1^{\circ} \mathrm{C}$. Carbon dioxide becomes supercritical and subcritical when it is above and slightly below its critical point, respectively. This study aims to determine the effect of high-pressure $\mathrm{CO}_{2}$ treatments at a pressure of $900 \mathrm{psi}, 950 \mathrm{psi}$ (subcritical), and $1100 \mathrm{psi}$ (supercritical) and at holding times of 5,10 , and $15 \mathrm{~min}$ on the quality parameters of white shrimp (Litopenaeus vannamei) and to determine the shelf life of white shrimp processed with the best treatment. The results showed that the interaction between pressure and holding time had a significant $(p<0.05)$ effect on cholesterol, protein, moisture content, and $b *$ value, but pressure had a significant effect on carotene content. The best treatment was a supercritical $\mathrm{CO}_{2}$ treatment at 1100 psi for 10 min, which was determined based on a significant reduction in the number of microorganisms and no significant changes in color, texture, and fat content were observed compared with control. The best treatment was applied to process shrimps, which were then stored at $4^{\circ} \mathrm{C}$ to evaluate the effectiveness of $\mathrm{scCO}_{2}$ treatment on the shelf life. No significant changes were found in PV and lipid in treated and $\mathrm{scCO}_{2}$-treated shrimps during storage, but the treatment significantly affected $\mathrm{pH}$, TVBN, and microbial counts. Among the samples, there was no hedonic difference in all sensory attributes. Supercritical $\mathrm{CO}_{2}$ treatment at 1100 psi for 10 min can be an alternative method for preservation of shrimps.
\end{abstract}

\section{Introduction}

White shrimp (Litopenaeus vannamei) has highly distinctive nutritional value and powerful antioxidants but is of fast deterioration, which results in an unpleasant odor, color, soft texture, and loss of acceptability. Several research works have been carried out to prevent shrimp deterioration during handling, including the application of conventional and nonthermal high-pressure carbon dioxide (HPCD) processing methods. However, there were some drawbacks to applying the first techniques, such as the occurrence of temperature abuse, loss of flavor and acceptability of drying shrimp, destruction of nutritional value, and loss of vitamins and bioactive components during heat treatment $[1,2]$. A new method of nonthermal HPCD technology has also been investigated as alternatives. This technique may overcome some weaknesses of conventional methods of shrimp handling techniques because it maintains the nutritional and sensorial quality of the foods while keeping freshness and flavor. High-pressure carbon dioxide is a nonthermal processing or a cold pasteurization method, where $\mathrm{CO}_{2}$ is above its critical point (supercritical region) and becomes supercritical fluid. $\mathrm{CO}_{2}$ in the form of supercritical fluid has a density like liquid, so it has a high solubility and diffusion due to the loss of boundary between the liquid and gas phases. The $\mathrm{CO}_{2}$ fluid density is highly compressible, in 
which a slight increase in pressure can lead to a large increase in fluid, making it possible to produce changes in the macromolecule and micromolecules of foods. Moreover, supercritical $\mathrm{CO}_{2}$ fluid tends to be nonpolar organic compounds, owing to its low polarity and lack of capacity for specific molecule interactions [3,4]. Several studies on the application of high-pressure $\mathrm{CO}_{2}$ for shrimp processing have been carried out, mainly with changing of temperature and $\mathrm{CO}_{2}$ pressure. $\mathrm{HPCD}$ at $310 \mathrm{bar}(31 \mathrm{MPa}), 1875 \mathrm{~L}$ of $\mathrm{CO}_{2}$, and $37^{\circ} \mathrm{C}$ was to produce low-cholesterol shrimps [5], and that at $20 \mathrm{MPa}$ was for the prevention of shrimp melanosis [6]. HPCD in the range of $20-25 \mathrm{MPa}$ and $37^{\circ} \mathrm{C}$ was performed for kinetic inactivation of PPO [7], while extraction of shrimp-waste astaxanthin was performed at $200 \mathrm{MPa}$ for 5 min with the use of ethanol cosolvent [8].

From those findings, the $\mathrm{CO}_{2}$ pressure used to process the shrimp was quite high $(14-31 \mathrm{MPa})$ and $37^{\circ} \mathrm{C}$. Additionally, use of a very high $\mathrm{CO}_{2}$ pressure at $800 \mathrm{MPa}$ resulted in toughening of shrimp texture and loss of flavor [9]. In fact, the critical point of $\mathrm{CO}_{2}$ is at a pressure of $7.38 \mathrm{MPa}$ and a temperature of $31.1^{\circ} \mathrm{C}[10]$, meaning that, at and above its critical point, $\mathrm{CO}_{2}$ exists as a gas and liquid in equilibrium, where an increase in temperature or pressure above this critical point does not result in further phase changes [11]. The $\mathrm{CO}_{2}$ fluid density is highly compressible; therefore, a slight change in temperature and pressure values can cause changes in the macromolecular and micromolecular structure of the shrimp, which, in turn, affect the quality of the shrimps. Additionally, the use of a very high $\mathrm{CO}_{2}$ pressure level may also lead to higher costs. Taking into account the above findings, our study used $\mathrm{CO}_{2}$ pressure treatments at supercritical $\mathrm{CO}_{2}(1100 \mathrm{psi} / 7.58 \mathrm{MPa})$ and subcritical $\mathrm{CO}_{2}(900 \mathrm{psi} / 6.21 \mathrm{MPa}$ and $950 \mathrm{psi} / 6.55 \mathrm{MPa})$. This study aimed to determine the effect of subcritical (900 and $950 \mathrm{psi})$ and supercritical (1100 psi) $\mathrm{CO}_{2}$ treatment at holding times of 5,10 , and 15 min on changes in shrimps' quality. The evaluated quality parameters included basic nutrients, color, microbiological, total carotene, cholesterol, texture, and muscle microstructure. The best treated shrimp was determined from the quality parameters that were not significantly different or the least changed compared with untreated shrimp. Then, it was stored at $4^{\circ} \mathrm{C}$ for 10 days to determine whether HPCD processing could prolong its shelf life. Spoilage indications, including the changes of lipid, PV, TVBN, $\mathrm{pH}$, and microbial levels, were monitored during storage.

\section{Materials and Methods}

2.1. Time and Place of Sampling. Freshly caught and additive-free white shrimp (Litopenaeus vannamei) (25-30 shrimps $/ \mathrm{kg}$ ) were purchased from a local farm in Palembang, Indonesia. The shrimps were kept in a sterile box ice (shrimps: ice $=1: 2$ ) and transported to the laboratory within $45 \mathrm{~min}$. Upon arrival, the shrimps were rinsed with tap water and stored in a low temperature $\left(2^{\circ} \mathrm{C}\right)$. Then, the fresh shrimps were run for high-pressure $\mathrm{CO}_{2}$ processing in the Laboratory of Processing, University of Sriwijaya, Palembang, Indonesia, where the unit of high-pressure $\mathrm{CO}_{2}$ processing instrument was located. Thereafter, processed shrimps were prepared for analytical tests or quickly packed in plastic container and kept in freezer $-20^{\circ} \mathrm{C}$ until they were needed. Following that, processed and unprocessed shrimps were analyzed for color, texture, and basic nutrients. For other analyses, such as cholesterol, carotene total, and microstructure (SEM), frozen samples were taken to the University of Lampung, Bandar Lampung, Indonesia, within 4 hours. It took 2 months to get all the data analyzed and find the best sample treatment. Thereafter, a storage study was performed in the Laboratory of Microbiology, University of Lampung, after previously processing HPCD samples in the processing laboratory. The whole study was conducted for 4 months from July to October 2020.

2.2. High-Pressure Carbon Dioxide (HPCD) Processing. The high-pressure $\mathrm{CO}_{2}$ installation used for experimental treatment consists of a $\mathrm{CO}_{2}$ gas cylinder, cylindrical pressure chamber, pressure gauges, and water bath at a constant temperature [12] (see Figure 1). Fresh shrimps were placed in a pressure chamber, which has been previously disinfected with $70 \%$ alcohol. Then, the chamber was tightly closed. When the designated temperature in the water bath was reached and all pipe connections were secured, commercially available $\mathrm{CO}_{2}$ (Pertamina, Jakarta, Indonesia) was injected through the gas inlet valve from the gas cylinder into the pressure chamber until it reached the desired pressures of 900,950 , and $1100 \mathrm{psi}$ (shown in pressure gauge) within $1 \mathrm{~min}$. After being subjected to high-pressure $\mathrm{CO}_{2}$ treatment for a defined pressurized time $(5,10$, and $15 \mathrm{~min})$, the pressure was lowered to atmospheric pressure within 3 minutes by slowly opening the gas outlet valve. Then, the shrimps were aseptically removed from the pressure chamber using a sterilized tong, placed in the sterilized container, and stored in a freezing temperature $\left(-20^{\circ} \mathrm{C}\right)$ before conducting an analysis such as SEM, but the samples were directly analyzed for microorganisms. The experiment was conducted in a full factorial design with the following factors: supercritical $\mathrm{CO}_{2}\left(\mathrm{scCO}_{2}\right)$ treatment at 1100 psi for 5,10 , and $15 \mathrm{~min}$ and subcritical $\mathrm{CO}_{2}\left(\right.$ sub- $\left.\mathrm{CO}_{2}\right)$ treatment at $950 \mathrm{psi}$ and $900 \mathrm{psi}$. The holding time for each of the pressure treatments was 5, 10, 15, and $20 \mathrm{~min}$. Each treatment was replicated three times.

2.3. Scanning Electron Microscope (SEM). Analysis of shrimp microstructure was conducted by scanning electron microscope (SEM, JSM-6310LV, JEOL Ltd.) following the procedures of Plascencia Jatomea and Viniegra et al. [13], adjusted to the shrimps' sample. Cross- and longitudinal sections of shrimp muscle $(0.5 \times 0.5 \mathrm{~cm})$ were chemically prefixed with $2.5 \%(\mathrm{v} / \mathrm{v})$ glutaraldehyde in $0.1 \mathrm{~mol} / \mathrm{L}$ at $\mathrm{pH}$ 7.0 PBS (phosphate-buffered saline), overnight at $4^{\circ} \mathrm{C}$. Then, postfix the sample with $1.0 \%(\mathrm{w} / \mathrm{v})$ osmium tetra oxide at room temperature for 1 hour. The specimens were washed in $50 \mathrm{mM}$ of PBS, pH 7.0 three times and then dehydrated for $15 \mathrm{~min}$ in a series of ethanol solutions graded at $30 \%, 50 \%$, $60 \%, 70 \%, 80 \%, 90 \%, 95 \%$, and $100 \%$, respectively. Following drying, the specimen then was coated in a gold coater by 


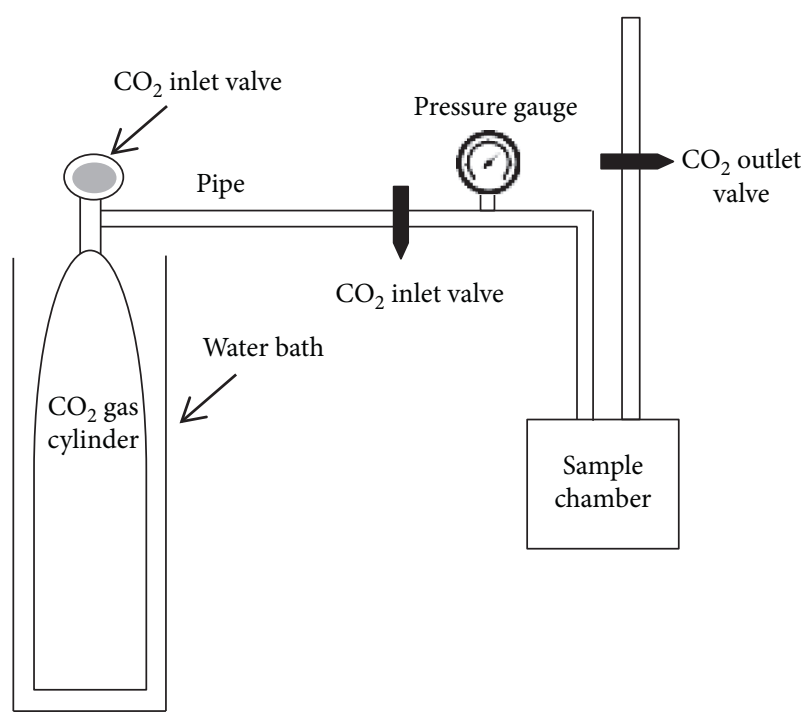

FIGURE 1: Schematic diagram of HPCD treatment equipment.

using IB3 ion coater tool for 5 minutes with an ions' current of 7-8 milliampere. Finally, the specimen was observed with ACC $20 \mathrm{kV}$-voltage devices at 100x, 250x, and 500x magnification.

2.4. Microbial Analysis. Microbial analysis in treated shrimp was expressed in terms of the relative survivor fraction, log (N/No), where $N$ is the number of colony-forming units per gram of sample (CFU/g) after treatment and No is the number of colony-forming units per gram (CFU/g) of sample before treatment. Each experiment was performed in duplicate, and the average values were reported. Total aerobic count was performed using the spread plate agar technique. First, the shrimp samples $(10.0 \pm 0.2 \mathrm{~g})$ were collected aseptically and placed in the sterile stomacher bag homogenized with $90 \mathrm{~mL}$ of $0.85 \%$ sterile saline solution for $2 \mathrm{~min}$. Next, serial dilutions of $10^{-1}, 10^{-2}$, and $10^{-3}$ were prepared with $0.85 \%$ sterile saline solution. Subsequently, $0.1 \mathrm{~mL}$ of each dilution was spread on to plate count agar (Difco, Detroit, MI, USA) for total aerobes.

2.5. Color and Texture Analysis. The colors of untreated shrimps and treated ones with high-pressure $\mathrm{CO}_{2}$ were measured using a colorimeter (Konica Minolta C-400, Tokyo, Japan) using CIELAB system. In this color system, the $L^{*}$ (lightness) variable represents the brightness, in which $L^{*}=0$ for dark and $L^{*}=100$ for white. The $a^{*}$ (redness) scale ranges from negative values $\left(-a^{*}\right)$ for green to positive values $\left(+a^{*}\right)$ for red, and $b^{*}$ (yellowness) scale ranges from negative values $\left(-b^{*}\right)$ for blue to positive values $\left(+b^{*}\right)$ for yellow. The chroma (C) value reflects the color intensity, where the brighter the color, the lower the $\mathrm{C}$ value. The notation of hue $\left({ }^{\circ} \mathrm{H}\right)$ indicates the dominant color, where negative ${ }^{\circ} \mathrm{H}$ has a range color of yellow-green; positive ${ }^{\circ} \mathrm{H}$ values have a range color of yellow-red. The colorimeter employed was firstly calibrated with a black standard followed by a white standard to obtain the final setting. The shrimp meat was placed in an optically clear Petridis glass. For each sample, three measurements were performed at the ventral body (second segment) of shrimp muscle, and the average values of the three samples were recorded.

The texture in terms of hardness was measured by using a LFRA Texture Analyzer (Brookfield AMETEK CT3-4500115CT3). Immediately after processing with HPCD, the sample was placed on a platform and a needle probe $(50 \mathrm{~mm}$ diameter) attached to a $25 \mathrm{~kg}$ load cell. The texture analyzer was set to a test speed of $5.0 \mathrm{~mm} / \mathrm{s}$, posttest speed of $10 \mathrm{~mm} / \mathrm{s}$, target distance of $30.0 \mathrm{~mm}$, and acquisition rate of $200 \mathrm{pps}$. A measurement was in gram force $\left(\mathrm{m}^{2} /\right.$ probe diameter), where a high value of measurement indicates an increase in shrimp hardness. For each sample, three measurements were performed, and the average value was recorded.

2.6. Cholesterol Analysis. The extraction of cholesterol was following the methodology essayed by Saldanha et al. [14] and derivatization with TMS (trimethylsilyl) ethers. The TMS derivatives were diluted in $1 \mathrm{~mL}$ hexane, filtered through a $22 \mu \mathrm{M}$ filter (Millipore, Maryland, MD, USA) and injected into a gas chromatograph (Shimadzu GC 2010, Tokyo, Japan) equipped with a split injector $(1: 50)$ and a flame ionization detector and capillary column Rtx-5-MS (30 $\mathrm{m} \times 0.25 \mathrm{~mm} \times 0.25 \mu \mathrm{m}$ Restek, Bellefonte, USA). The operation conditions were as follows: an initial temperature of $230^{\circ} \mathrm{C}(0 \mathrm{~min})$; heating rate of $2^{\circ} \mathrm{C} / \mathrm{min}$ up to $264^{\circ} \mathrm{C}$ ( $5 \mathrm{~min})$; and then a heating rate of $1^{\circ} \mathrm{C} / \mathrm{min}$ up to a final temperature of $275^{\circ} \mathrm{C}(2 \mathrm{~min})$. The injector and detector temperatures were $350^{\circ} \mathrm{C}$ and $290^{\circ} \mathrm{C}$, respectively. The carrier gas used was hydrogen at a flow rate of $1 \mathrm{~mL} / \mathrm{min}$. Cholesterol identification was performed by comparing sample retention times with standard retention times (Sigma, Milford, MA, USA). The quantification was performed by an external calibration curve with 10 points, at concentrations ranging from 10 to $1000 \mu \mathrm{g} / \mathrm{mL}$.

2.7. Total Carotenoid Analysis. The concentration of total carotenoids was measured using the spectrophotometric modified method from treated and untreated shrimp [15]. To prepare the standard graph, different volumes $0.2,0.4$, $0.6,0.8,1.0$, and $1.2 \mathrm{ml}$ stock solutions of astaxanthin (1\%) were made, and the solutions were diluted up to $10 \mathrm{ml}$ with $\mathrm{n}$-hexane. The absorbance was measured at $472 \mathrm{~nm}$ using $\mathrm{n}$-hexane as the blank. The experiment was performed in triplicate; the standard graph for astaxanthin was constructed.

2.8. Basic Nutrient Analysis. Water content, crude protein, fat, and ash were measured following the standard methods [16]. Weight differences were recorded after drying the samples in a hot air oven at $100 \pm 5^{\circ} \mathrm{C}$ overnight to determine the water content. Protein content was measured by using the micro-Kjeldahl method. Crude fat was measured by Soxhlet extraction with diethyl ether. Ashing was done by incineration in a muffle furnace at $550 \pm 50^{\circ} \mathrm{C}$ until white ash was obtained. 


\subsection{Storage Study}

2.9.1. Determination of $p H, T V B-N$, and $P V$ during Storage. Determination of $\mathrm{pH}$ was performed using a $\mathrm{pH}$ meter (Seven Go Duo ${ }^{\mathrm{TM}}$, Mettler Toledo Inc., Columbus, $\mathrm{OH}$, USA). The $\mathrm{pH}$ of all shrimp samples was determined at ambient temperature. Approximately $20 \mathrm{~g}$ of shrimp was homogenized with $80 \mathrm{~mL}$ distilled water using Warring ${ }^{\circledR}$ Blender (USA). Prior to use, calibration of the Seven Go Duo $\mathrm{pH}$ Meter probes was done using standard buffers of $\mathrm{pH}$ 4.0.

The determination of TVB was performed following the National Standardization Body [17]. Approximately $5 \mathrm{~g}$ of shrimp flesh was homogenized with $15 \mathrm{~mL}$ of $4 \%$ trichloroacetic acid (TCA) (w/v) and centrifuged at $3000 \mathrm{~g}$ for $3 \mathrm{~min}$ and then filtered through filter paper. An aliquot of $5 \mathrm{~mL}$ was removed and mixed with $5 \mathrm{~mL}$ of $2 \mathrm{M} \mathrm{NaOH}$. The mixture was poured into a semi-microdistillation tube and steam distillation was performed. The distillate was collected in a beaker containing $15 \mathrm{~mL}$ of $0.01 \mathrm{HCl}$ containing $0.1 \mathrm{~mL}$ rosolic indicators. Titration was performed using $0.01 \mathrm{M}$ $\mathrm{NaOH}$ to a pale end point.

Determination of peroxide value (PV) was done following the procedure IFRA [18]. Approximately $5 \mathrm{~g}$ of shrimp flesh was homogenized with $30 \mathrm{ml}$ of solution of glacial acetic acid: chloroform (3:2) in $250 \mathrm{~mL}$ Erlenmeyer flask for $30 \mathrm{sec}$. To the homogenate, $1 \mathrm{~mL}$ of saturated potassium iodide (KI) solution was added, and it was allowed to react for $1 \mathrm{~min}$ by agitating. Then, $30 \mathrm{~mL}$ aquades was added. An equivalent $(50 \mathrm{~mL})$ amount of distilled water was added to the mixture to release the iodine and solution titrated with $0.01 \mathrm{M}$ sodium thiosulphate solution against blank. PV was calculated and expressed as mEq active $\mathrm{O}_{2} / \mathrm{kg}$ lipids.

2.9.2. Sensory Analysis of Shrimps during Storage. Sensory analysis was performed to determine the effect of high-pressure $\mathrm{CO}_{2}$ (HPCD) processing on the preferences and organoleptic properties of shrimps during storage. Hedonic test was used to determine the preference level of untreated and treated shrimps based on hedonic scale. DuoTrio test was used to determine whether a perceptible sensory difference exists between samples of two products, untreated and treated shrimp with HPCD. All samples including untreated and treated shrimps with HPCD were assessed. For the Hedonic test, all samples were evaluated by 10 untrained panelists using a five-point hedonic scale, ranging from 5 = like extremely to $1=$ dislike extremely [19]. They were asked to evaluate overall likeness, texture, and aroma. For the Duo-Trio test, a set of three samples of shrimps was served to each of the 20 panels, of which one sample was labeled as a reference and the other two samples had different codes. The panels were informed that one of the coded samples was the same as the reference and one was different, and then, they are asked to report which of the coded samples they believe to be different most from the reference (control) and write down the differences in terms of each of the three parameters: color, texture, and odor. The number of correct responses is counted, and the significance is determined by reference to a statistical table [20]. The study was run twice, and the average value was taken. This study does not require ethical approval.

2.10. Statistical Analysis. Statistical analyses were performed using SPSS package (SPSS 23.0 for windows, SPSS Inc., Chicago, IL, USA). The data of the parameters, including basic nutrient, carotenoids, cholesterol, color values, texture, and microbial counts, obtained from the treatments were subjected to an analysis of variance (one-way ANOVA) to determine the significance between samples. Data obtained from the storage study, including parameters such as $\mathrm{pH}$, TVBN, microbial counts, lipid, and PV, were also run for one-way ANOVA. A Duncan's test was used to compare the means of parameter analysis in the experiment. The means with different letters were significantly different at $p \leq 0.05$. Data represent the means \pm SD of measurement for three replicates.

\section{Results and Discussion}

The ANOVA and $t$-test (Table 1) indicated that highpressure $\mathrm{CO}_{2}$ (subcritical and supercritical) significantly affected carotene, microbial reduction, moisture, protein, and chrome color $(p \leq 0.05)$. However, holding time did not significantly affect the hardness, fat, $L^{*}, a^{*}$, and hue color of treated shrimp $(p \geq 0.05)$. The interaction of the pressure and holding time significantly affected the cholesterol, moisture, ash, protein, $b^{*}$, and chrome color of treated shrimp $(p \leq 0.05)$.

3.1. Effect of High-Pressure Treatment on Color, Texture, and Microstructure. High-pressure $\mathrm{CO}_{2}$ treatments did not significantly $(p \geq 0.05)$ change the color and texture of the shrimps. Table 2 shows the effect of the treatments on the color changes. Raw shrimps appeared slightly opaque and translucent with low color intensity $(C)$ and very low dominant color $\left({ }^{\circ} \mathrm{H}\right)$ of yellow-red. After treatment at 900 psi, the shrimps turned slightly pink, low color intensity (C), and low dominant of yellow-red. When pressure treatment increased, the samples were dominant in slight pink color, with higher intensity in pale white, which was more pronounced at 1100 psi. This was related to the decrease in carotenoid (Table 3), meaning that astaxanthin was released. This result can be explained that the more release of astaxanthin in shrimp matrix, the more intense the color change. Youn et al. [21] and Sánchez-Camargo et al. [22] reported that the higher supercritical $\mathrm{CO}_{2}$ pressure resulted in a significant increase of astaxanthin solubility and extract yield. $\mathrm{CO}_{2}$ was a good solvent for astaxanthin due to its similar polarity, and therefore, the higher the pressure, the more intense the extraction, releasing free astaxanthin. In our study, the slight discoloration of shrimp may be due to the weakening of physical interactions in the carotenoprotein molecules in the shrimp meat. Diffused $\mathrm{CO}_{2}$ reduces water density and creates hydrophobic microenvironments. It can break the interaction between protein and astaxanthin by dissolving isoprene units linked by 
TABLE 1: Statistical analysis of the effects of HPCD parameters on the qualities of treated shrimps.

\begin{tabular}{lccc}
\hline Parameters & \multicolumn{3}{c}{$P$ values } \\
& Pressure $(P)$ & Time $(T)$ & $P \times T$ \\
\hline Carotene & 0.000 & - & - \\
Microbial reduction & 0.000 & 0.000 & 0.200 \\
Cholesterol & 0.063 & 0.024 & 0.000 \\
Hardness & 0.350 & 0.985 & 0.989 \\
\hline Basic nutrient & & & \\
Moisture & 0.019 & 0.005 & 0.011 \\
Ash & 0.853 & 0.008 & 0.064 \\
Fat & 0.053 & 0.854 & 0.809 \\
Protein & 0.047 & 0.000 & 0.000 \\
Carbohydrate & 0.006 & 0.003 & 0.493 \\
\hline Color & & & \\
$L$ & 0.143 & 0.315 & 0.855 \\
$a^{*}$ & 0.178 & 0.280 & 0.575 \\
$b^{*}$ & 0.622 & 0.002 & 0.004 \\
$C$ & 0.016 & 0.003 & 0,001 \\
$H$ & 0.974 & 0.065 & 0.132 \\
\hline
\end{tabular}

Significantly different at $p \leq 0.05$.

conjugated double bonds and produce a slight pink color $\left(a^{*}=5.85, ? L^{*}=61.35\right)$. In shrimp and salmon, astaxanthin is conjugated with protein to form carotenoprotein molecules. Astaxanthin does not bind to protein but only physically interacts, where there is an intermolecular force between astaxanthin and protein molecules [23]. Hydroxyl and ketone groups in the end ring structure, which are bound to the hydrophilic part of the protein membrane, are polar molecules, while the isoprene unit is attached to the hydrophobic part of the protein membrane and is nonpolar. Colors produced by carotenoid pigments ranges from blue to red due to the presence of double bonds structure [24].

This color changes could relate to the change of texture and microstructure found in this study. In the microstructure view (Figure 2), we found that the supercritical $\mathrm{CO}_{2}$ caused the muscle fiber structure to swell due to protein denaturation. This was associated with a decrease in protein content (Table 4). Monhemi and Dolatabadi [4] reported the complete denaturation occurred between 800 and 1400 MPA. Proteins are completely denatured when their secondary structure consisting of amino acids linked by hydrogen bonds is broken. Denaturation affects the shrinkage of the sarcomere and the breaking of muscle fibers. As $\mathrm{CO}_{2}$ diffused in the aqueous meat matrix, it reduced water density protein, and muscle fiber structure became dense forming a larger sarcomeric space. Yan et al. [25] found that denaturation of sarcoplasmic protein produced paler color of meat treated with high-pressure $\mathrm{CO}_{2}$.

The changes of shrimp's texture and microstructure of the shrimps are related to protein content and water-holding capacity. Figure 3 displays the histogram of the hardness of treated and untreated shrimp at various pressures and holding time. When the protein denatured and collagen shrank, shrimp muscles lost their water-holding capacity, leading to changes of hardness. In our study, there was the possibility of partial denaturation of shrimp protein in our experiment. At a pressure of 900, 950, and 1100 psi, highcompressibility $\mathrm{CO}_{2}$ interacts with the hydrophobic bonds in the protein, which causes unfolding of its tertiary structure. The unfolded protein structure increases their surface hydrophobicity allowing new intra- and interprotein interaction, thereby resulting in a dense protein structure. During the release of $\mathrm{CO}_{2}$ pressure, the unfolded protein structure may return to its native structure and allow the rehydration of protein, resulting in the less hard texture. This may explain the slight change in the texture of the shrimps.

\subsection{Effect of High-Pressure Treatment on Basic Nutrients.} A whole shrimp consists of head, shell, meat muscle, and tail. The main part is the meat, accounting for $48 \%$ of the shrimp [26]. The chemical analysis of fresh and treated shrimp is presented in Table 4. It showed that the range of values for protein, fat, and ash content in all of the processed shrimps was $16.04-18.89 \%, 0.23-0.53 \%$, and $0.7-1.54 \%$ (w/w, wetweight basis), respectively. The results were similar to those reported by Venugopal [27], who found the protein and fat levels of $L$. vannamei were ranging from 17.0 to 23.0 and 0.37 to 0.88 , respectively, with myosin and actin being the predominant proteins. Tabitha and Anand [26] showed that protein, carbohydrate, lipid, moisture, and ash content of L. vannamei from India were 35.69, 3.20, 19, 76.2, and 1.2\% (dry basis), respectively.

As shown in Table 4, high-pressure $\mathrm{CO}_{2}$ (HPCD) treatment significantly affected the protein content of shrimp ( $p \leq 0.05)$ with the fluctuating value. The protein of untreated shrimp was $18.09 \%$, and the treated shrimp at 1100 psi for $15 \mathrm{~min}$ was $18.21 \%$. The lowest content, $16.04 \%$, was shrimp treated at 900 psi for $5 \mathrm{~min}$. In this study, the change in protein content can be due to molecular polarity and interactions of supercritical $\mathrm{CO}_{2}$ with amino acid side chains. Shrimp proteins have an appreciable amount of the essential amino acids, that is, leucine, isoleucine, lysine, valine, threonine, methionine, phenyl alanine, and cysteine, and good content of glycine, glutamic acid, alanine, and proline [27]. Leucine, isoleucine, valine, methionine, phenyl alanine, alanine, and cysteine are hydrophobic residues of nonpolar molecules, while threonine, lysine, glycine, and glutamic acid are hydrophilic residues of polar molecules. During the high-pressure $\mathrm{CO}_{2}$ treatment, $\mathrm{CO}_{2}$ molecules diffused to the protein matrix, made a hydrophobic microenvironment, and lead to adsorption of nonpolar hydrophobic amino acids. This causes reduction in protein content. Polar hydrophilic amino acid residues escape from the hydrophobic microenvironment and form nonnative hydrogen bonds with other hydrophilic residues. This nonnative interactions lead to the protein denaturant in the high-pressure $\mathrm{CO}_{2}$-treated protein. This may explain the fluctuated value of protein in the study. $\mathrm{CO}_{2}$ is regarded as hydrophobic fluid at supercritical $\mathrm{CO}_{2}$ and is a proper solvent for most nonpolar and slightly polar molecules $[4,28]$. Meanwhile, subcritical $\mathrm{CO}_{2}(900 \mathrm{psi})$ tends to attract slight polar molecules [3].

There was no significant difference $(p \geq 0.05)$ in fat content in all samples, meaning that there was no correlation 
TABLE 2: Effects of various pressures and holding times on color attributes of white shrimps (Litopenaeus vannamei).

\begin{tabular}{|c|c|c|c|c|c|}
\hline \multirow{2}{*}{ Pressure (psi)/holding time (min) } & \multicolumn{5}{|c|}{ Color } \\
\hline & $\Delta L^{*}$ & $a^{*}$ & $b^{*}$ & Chrome & Hue \\
\hline Untreated & $51.55 \pm 0.77 \mathrm{a}$ & $4.15 \pm 0.07 a$ & $4.65 \pm 0.49 c$ & $4.0 \pm 0.92 \mathrm{a}$ & $20.2 \pm 2.05 a$ \\
\hline $900 / 5$ & $51.65 \pm 0.77 \mathrm{a}$ & $5.55 \pm 1.62 \mathrm{bc}$ & $7.6 \pm 1.55 \mathrm{e}$ & $7.5 \pm 0.85 c$ & $45.7 \pm 0.78 \mathrm{~cd}$ \\
\hline $900 / 10$ & $54.15 \pm 1.10 \mathrm{ab}$ & $5.15 \pm 0.49 \mathrm{ab}$ & $4.5 \pm 0.71 c$ & $9.0 \pm 1.48 \mathrm{e}$ & $45.6 \pm 1.2 \mathrm{~cd}$ \\
\hline $900 / 15$ & $59.1 \pm 2.96 \mathrm{~cd}$ & $5.25 \pm 2.05 b$ & $8.0 \pm 2.12 \mathrm{ef}$ & $8.8 \pm 1.48 \mathrm{de}$ & $45.8 \pm 11.8 \mathrm{~cd}$ \\
\hline $950 / 5$ & $53.75 \pm 0.71 \mathrm{ab}$ & $5.0 \pm 0.71 \mathrm{ab}$ & $9.55 \pm 0.21 \mathrm{~g}$ & $8.9 \pm 0.07 \mathrm{de}$ & $45.2 \pm 8.91 \mathrm{~cd}$ \\
\hline $950 / 10$ & $52.05 \pm 1.34 \mathrm{a}$ & $4.05 \pm 0.07 \mathrm{a}$ & $2.05 \pm 0.35 a$ & $4.7 \pm 0.28 \mathrm{ab}$ & $36.4 \pm 4.31 b$ \\
\hline $950 / 15$ & $54.9 \pm 6.64 \mathrm{ab}$ & $5.6 \pm 0.14 b c$ & $8.75 \pm 0.21 \mathrm{f}$ & $9.1 \pm 0.35 \mathrm{e}$ & $56.8 \pm 0.49 \mathrm{~d}$ \\
\hline $1100 / 5$ & $59.75 \pm 4.45 c$ & $5.25 \pm 0.91 b$ & $3.85 \pm 1.34 \mathrm{~b}$ & $6.5 \pm 0.28 b$ & $43.2 \pm 2.19 c$ \\
\hline $1100 / 10$ & $56.75 \pm 3.88 \mathrm{bc}$ & $5.85 \pm 1.20 c$ & $6.65 \pm 1.76 \mathrm{~d}$ & $6.6 \pm 0.35 b$ & $45.1 \pm 3.61 \mathrm{~cd}$ \\
\hline $1100 / 15$ & $61.35 \pm 0.21 c$ & $6.1 \pm 0.71 c$ & $7.75 \pm 2.19 \mathrm{ef}$ & $8.1 \pm 0.64 \mathrm{~d}$ & $48.1 \pm 2.47 c d$ \\
\hline
\end{tabular}

Different letters in the same column indicate significance differences $(p \leq 0.05)$ between the treatments. Results represent an average of 3 replications and standard deviation.

TABLE 3: Effects of various pressures and holding times on cholesterol, total carotene content, and microbial reduction in white shrimps (Litopenaeus vannamei).

\begin{tabular}{|c|c|c|c|}
\hline Pressure (psi)/holding time (min) & Cholesterol (mg/g) & Total carotene $(\mathrm{mg} / \mathrm{g})$ & Microbial reduction $(\log \mathrm{N} / \mathrm{No})$ \\
\hline Control & $1.63 \pm 0.34 \mathrm{f}$ & $4.24 \pm 0.33 \mathrm{a}$ & \\
\hline $900 / 5$ & $1.39 \pm 0.28 \mathrm{~cd}$ & $3.80 \pm 1.09 \mathrm{~b}$ & $0.983 \pm 0.00 \mathrm{a}$ \\
\hline $900 / 10$ & $1.27 \pm 0.32 \mathrm{a}$ & $3.78 \pm 0.09 b c$ & $0.979 \pm 0.00 \mathrm{ab}$ \\
\hline $900 / 15$ & $1.46 \pm 0.29 \mathrm{de}$ & $3.79 \pm 0.64 b c$ & $0.974 \pm 0.00 \mathrm{bc}$ \\
\hline $950 / 5$ & $1.47 \pm 0.32 \mathrm{de}$ & $3.77 \pm 2.02 \mathrm{c}$ & $0.974 \pm 0.00 \mathrm{bc}$ \\
\hline $950 / 10$ & $1.39 \pm 0.34 \mathrm{de}$ & $3.76 \pm 0.37 c$ & $0.969 \pm 0.00 c$ \\
\hline $950 / 15$ & $1.36 \pm 0.34 b c$ & $3.69 \pm 0.55 c$ & $0.952 \pm 0.00 \mathrm{~d}$ \\
\hline $1100 / 5$ & $1.46 \pm 0.33 \mathrm{de}$ & $2.51 \pm 0.29 \mathrm{~d}$ & $0.803 \pm .00 \mathrm{e}$ \\
\hline $1100 / 10$ & $1.48 \pm 0.31 \mathrm{e}$ & $2.37 \pm 0.06 \mathrm{~d}$ & $0.805 \pm 0.00 \mathrm{e}$ \\
\hline $1100 / 15$ & $1.34 \pm 0.29 \mathrm{ab}$ & $2.29 \pm 0.12 \mathrm{~d}$ & $0.793 \pm 0.00 f$ \\
\hline
\end{tabular}

Means with the same superscript letter in the same column were not significant different $(p \leq 0.05)$.

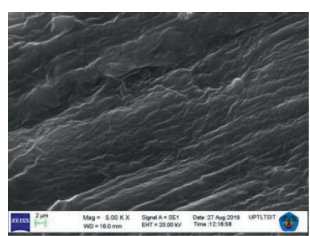

(a)

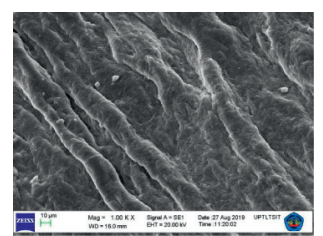

(b)

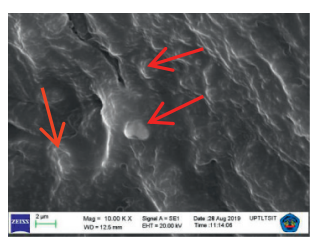

(c)

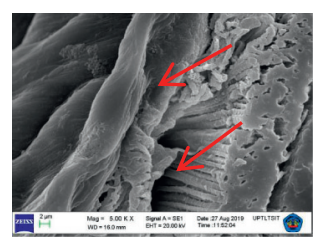

(d)

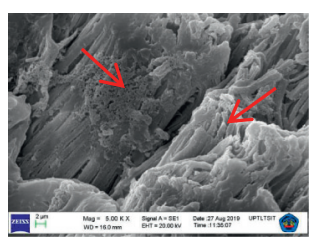

(e)

FIGURE 2: SEM images of microstructures of white shrimp with high-pressure $\mathrm{CO}_{2}$ treatments. (a) Raw shrimp muscle at transversal section showing a well-organized structure. (b) Raw shrimp muscle at longitudinal section. (c) Swollen muscle fiber due to protein denaturation identified in treated shrimps at 900 psi for $10 \mathrm{~min}$. (d) Denser muscle fiber and large sarcomeric space were formed in treated shrimps at 950 psi for $10 \mathrm{~min}$. (e) Shrinkage of sarcomere and broken muscle fiber identified in treated shrimps at 1100 psi for $10 \mathrm{~min}$.

between fat solubility and HPCD treatment at various pressures and holding time. The data showed that the fat content in untreated shrimps was $0.53 \%$, while, in treated shrimps, it ranged from $0.23 \%$ to $0.44 \%$. A similar finding reported that the fat content of Nila tilapia was not affected by $\mathrm{scCO}_{2}$ from 80 to 90 bars at $40^{\circ} \mathrm{C}$ [29]. On the contrary, fat content in tempeh reduced at $1100 \mathrm{psi}$ at $31^{\circ} \mathrm{C}$ [30]. Fat in foods is lipophilic and soluble in supercritical $\mathrm{CO}_{2}$; therefore, it decreased during HPCD processing. The explanation was related to the presence of protein, cholesterol, and other organic compounds in shrimps, which could act as a barrier effect on the solubility of fat-scCO 2 and the lower moisture content $(74 \%)$, which reduced the amount of $\mathrm{CO}_{2}$ able to dissolve in the food matrix; consequently, fat loss was not significant. Another study reported the protective effect of carbohydrate in foods on the inactivation of Brocothrix thermosphacta inoculated on minced and skinned beef treated with $\mathrm{HPCD}$ at $6.1 \mathrm{MPa}, 45^{\circ} \mathrm{C}$ for $150 \mathrm{~min}$ [31].

High-pressure $\mathrm{CO}_{2}$ did not have a significant effect $(p \geq 0.05)$ on the moisture of shrimps, although there was a decrease in moisture of up to $74 \%$ in shrimps treated with 1100 psi for $15 \mathrm{~min}$. There is no removal of water from the shrimps, but rather the pressured $\mathrm{CO}_{2}$ attracts water molecules by binding to the water and forming $\mathrm{HCO}_{3}^{-}$and $\mathrm{CO}_{3}^{-}$ ions and consequently reducing the water content. Increasing pressure and longer treatment time increased the solubility and mass transfer of $\mathrm{CO}_{2}$, thereby enhancing the decrease in water content as what happened in shrimps 
TABLE 4: Effects of high-pressure $\mathrm{CO}_{2}$ at various pressures and holding times on the proximate and microbial reduction.

\begin{tabular}{|c|c|c|c|c|}
\hline Pressure (psi)/holding time (min) & Moisture (\%) & Crude fat $(\%)$ & Crude protein $(\%)$ & Ash (\%) \\
\hline $900 / 5$ & $79.99 \pm 0.71 \mathrm{a}$ & $0.36 \pm 0.005 a$ & $16.04 \pm 0.08 \mathrm{f}$ & $0.70 \pm 0.03 a$ \\
\hline $900 / 10$ & $79.84 \pm 0.14 \mathrm{a}$ & $0.38 \pm 0.01 \mathrm{a}$ & $18.11 \pm 0.13 \mathrm{hi}$ & $0.99 \pm 0.1 \mathrm{ab}$ \\
\hline $900 / 15$ & $79.97 \pm 0.1 \mathrm{a}$ & $0.28 \pm 0.03 a$ & $16.75 \pm 0.12 \mathrm{a}$ & $0.99 \pm 0.1 b$ \\
\hline $950 / 5$ & $77.21 \pm 1.48 \mathrm{a}$ & $0.28 \pm 0.007 a$ & $18.20 \pm 0.14 \mathrm{hi}$ & $1.06 \pm 0.3 \mathrm{c}$ \\
\hline $950 / 10$ & $78.48 \pm 1.06 \mathrm{a}$ & $0.24 \pm 0.42 \mathrm{a}$ & $18.15 \pm 0.18 \mathrm{bcd}$ & $1.54 \pm 0.3 \mathrm{~cd}$ \\
\hline $950 / 15$ & $78.29 \pm 1.84 \mathrm{ab}$ & $0.60 \pm 0.45 a$ & $16.78 \pm 0.34 \mathrm{ab}$ & $0.81 \pm 0.12 \mathrm{~cd}$ \\
\hline $1100 / 5$ & $77.9 \pm 1.27 \mathrm{ab}$ & $0.78 \pm 0.45 a$ & $18.45 \pm 0.28 \mathrm{de}$ & $1.28 \pm 0.78 \mathrm{~cd}$ \\
\hline $1100 / 10$ & $74.96 \pm 0.6 \mathrm{ab}$ & $0.78 \pm 0.53 a$ & $18.94 \pm 0.13 \mathrm{fg}$ & $1.52 \pm 0.5 \mathrm{~cd}$ \\
\hline $1100 / 15$ & $74.38 \pm 1.42 \mathrm{bc}$ & $0.77 \pm 0.046 \mathrm{a}$ & $18.21 \pm 0.14 \mathrm{bc}$ & $1.03 \pm 0.04 \mathrm{~d}$ \\
\hline Untreated & $79.08 \pm 1.36 c$ & $0.29 \pm 0.021 \mathrm{a}$ & $18.09 \pm 0.68 \mathrm{~h}$ & $0.96 \pm 0.1 \mathrm{e}$ \\
\hline
\end{tabular}

Means with the same superscript letter in the same column were not significant different $(p \leq 0.05)$.

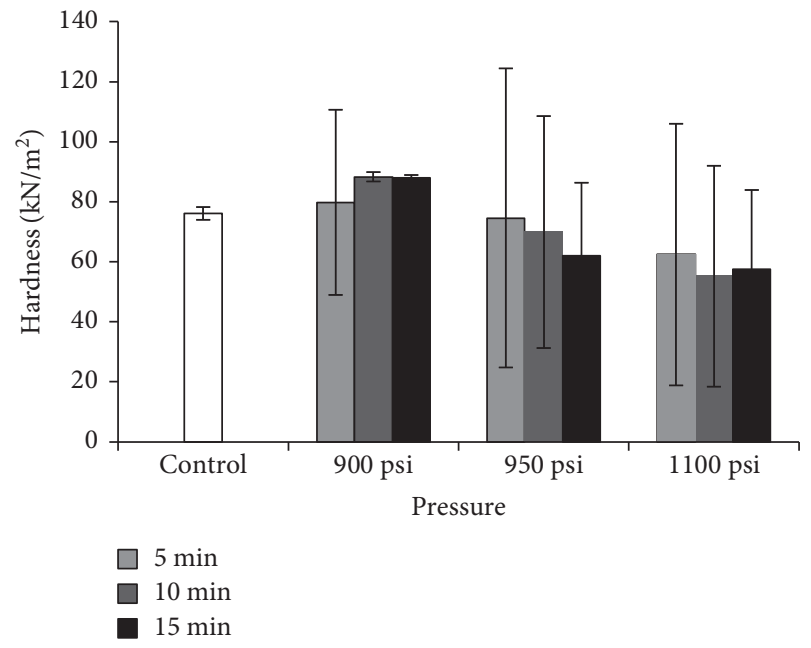

FIGURE 3: Texture of untreated and treated shrimps with HPCD at various pressures and holding times. The results represented the mean values obtained from 3 different samples and two replications.

treated with 1100 psi for $15 \mathrm{~min}$. Ash content of the shrimps treated at 1100 psi significantly increased $(p \leq 0.05)$ compared with the other samples. A decrease in moisture content can cause a relative increase in protein, fat, and ash [7].

3.3. Microbiological Analysis. Table 3 displays the reduction number of aerobic bacteria in treated shrimp with HPCD. The high-pressure treatment significantly destroyed bacteria $(p \leq 0.05)$ at 1100 psi. The number of aerobic bacteria in fresh shrimp (before treatment) and in treated shrimp at $1100 \mathrm{psi}$ was $4.5 \times 10^{5} \mathrm{CFU} / \mathrm{g}$ and $3.5 \times 10^{4} \mathrm{CFU} / \mathrm{g}$, respectively. In contrast, the number of microbes in tilapia decreased by $2 \log$ cycles at a pressure treatment of 80 bar reported by Sugiharto et al. [29]. Meanwhile, Kustyawati et al. [30] found that tempeh treated with 900 psi significantly $(p \leq 0.05)$ reduced the number of microbes by 2 logs. The type and chemical contents of products processed with supercritical $\mathrm{CO}_{2}$ could be the reason for inhibiting microbiological inactivation in treated shrimps in this study. Shrimps are a marine product that contains high protein, fat, minerals, and many bioactive compounds in their matrix, which can inhibit penetration of $\mathrm{CO}_{2}$ into the bacterial cells and prevent them from dying. Moreover, lower moisture (74\%) content due to the dissolution of $\mathrm{CO}_{2}$ into liquid shrimps, which dissociates and forms $\mathrm{HCO}_{3}{ }^{-}, \mathrm{CO}_{3}{ }^{-}$and $\mathrm{H}^{+}$ ions, could increase the bactericidal effect of high-pressure $\mathrm{CO}_{2}$ treatment. Erkem [31] showed that the bactericidal action of HPCD was more effective in a liquid substrate, where Brochothrix thermosphacta cells inoculated in brain-heart infusion broth were completely inactivated under $6.1 \mathrm{MPa}$ after $30 \mathrm{~min}$ at $45^{\circ} \mathrm{C}$, while it was reduced one $\log$ cycle, when the cells were inoculated in minced beef treated with HPCD at $6.1 \mathrm{MPa}$ and $45^{\circ} \mathrm{C}$ for $150 \mathrm{~min}$.

\subsection{Effect of High-Pressure Treatment on Cholesterol and Total} Carotene. Shrimps are rich in cholesterol even though they contain high nutrient quality of polyunsaturated fatty acids $[32,33]$. In this study, the effects of HPCD processing on cholesterol and total carotene in shrimp were measured and displayed in Table 3. It showed that HPCD processing significantly decreased $(p \leq 0.05)$ cholesterol and total carotene content in shrimps. The initial cholesterol content in untreated shrimps was $1.63 \mathrm{mg} / \mathrm{g}$. Cholesterol levels in treated shrimps fluctuated between 1.27 and $1.48 \mathrm{mg} / \mathrm{g}$, and the lowest level was reached at 900 psi for $10 \mathrm{~min}$ of holding time. Compared with the study conducted by HigueraCiapara et al. [5], which found that cholesterol was extracted in supercritical $\mathrm{CO}_{2}\left(310\right.$ bar; $\left.37^{\circ} \mathrm{C}\right)$, our findings suggest that cholesterol was extracted in both subcritical $\mathrm{CO}_{2}$ (900 psi) and supercritical $\mathrm{CO}_{2}$ (1100 psi). This can be explained by considering the molecular polarity and solubility of $\mathrm{CO}_{2}$. In the supercritical region, supercritical $\mathrm{CO}_{2}$ $\left(\mathrm{scCO}_{2}\right)$ possesses high solubility, where the density of $\mathrm{scCO}_{2}$ increased with increasing pressure, so that more cholesterol was extracted. In the subcritical region slightly below the critical point, $\mathrm{CO}_{2}$ can be a liquid, which is more polar, and cholesterol can most likely be extracted in this $\mathrm{CO}_{2}$ phase [34]. Below the critical point and above the triple point of $-56.6^{\circ} \mathrm{C}$ and $0.52 \mathrm{MPa}, \mathrm{CO}_{2}$ exists as a liquid. At and above the critical temperature of $31^{\circ} \mathrm{C}$ and critical pressure of $7.35 \mathrm{MPa}$ (critical point), $\mathrm{CO}_{2}$ exists as a gas and liquid in equilibrium; increasing temperature or pressure above this critical point does not result in any further phase changes. Cholesterol $\left(\mathrm{C}_{27} \mathrm{H}_{46} \mathrm{O}\right)$ is mostly a nonpolar hydrocarbon compound [33], but cholesterol is water-soluble because it 
has a polar $\mathrm{OH}$ functional group, so more cholesterol is extracted at 900 psi. Cholesterol levels of all processed shrimps in our study were in accordance with the recommended daily intake ( $<300 \mathrm{mg} /$ day) [35]. However, one needs to be cautious about including shrimps in diet, because the normal total cholesterol in human blood is $160-200 \mathrm{mg} / 100 \mathrm{~g}$. The higher the cholesterol level in the blood, the greater the risk of atherosclerosis, which is the thickening and hardening of the artery wall due to cholesterol build-up [36].

The effect of HPCD processing on total carotenoid content in shrimps is displayed in Table 4. It showed that HPCD processing significantly reduced $(p \leq 0.05)$ total carotenoid in shrimps. Fresh shrimps contained $4.53 \mathrm{mg} / \mathrm{g}$ of total carotenoid. With increasing pressure, more carotenoid was extracted, as in this study the lowest carotenoid content was $2.29 \mathrm{mg} / \mathrm{g}$ in shrimps treated at 1100 psi for 10 minutes. A similar finding reported by Mezzomo and Ferreira [37] and Radzali et al. [38] was that $\beta$-carotene in shrimps was highly extracted and pressure-dependent. A study on the effect of HPCD on the degradation of anthocyanin showed that there was no reduction after $30 \mathrm{MPa}, 45^{\circ} \mathrm{C}$, but when pressure was increased to $60 \mathrm{MPa}, 55^{\circ} \mathrm{C}$, for $30 \mathrm{~min}$, anthocyanin decreased [39]. Another study reported that $\beta$-carotene in the Dunaliella salina microalgae was extracted at a higher pressure (400 bar and $65^{\circ} \mathrm{C}$ ) [40]. In this our study, solubility of $\mathrm{CO}_{2}$ and food matrix may influence reduction of carotenoid in treated shrimps. As the pressure increased, the density increased, enhancing the solubility of $\mathrm{CO}_{2}$, and therefore, more carotenoid was extracted. Carotenoid is a nonpolar molecule of fat-soluble pigment, which easily interacts with nonpolar $\mathrm{CO}_{2}$, resulting in reduction of carotenoid. However, high diffusion of $\mathrm{CO}_{2}$ can alter the conformation of the protein, leading to denaturation, and result in carotenoid extraction.

3.5. Storage Study. The storage study aimed to evaluate the effectiveness of high-pressure $\mathrm{CO}_{2}$ treatment on the shelf life of shrimps. According to the study, the best treatment was at the pressure of $1100 \mathrm{psi}$ and holding time of 10 minutes (Table 5). Shrimps were then treated with the best treatment and stored at $4^{\circ} \mathrm{C}$ for 10 days. The changes in quality parameters, including microbial count, lipid, $\mathrm{PV}, \mathrm{pH}$, and formation of total volatile base nitrogen (TVB-N), were monitored (Figures 4-8). TMA level was not monitored in this study due to the limited availability of the chemical during COVID-19. No significant changes were found $(p \leq 0.05)$ in $\mathrm{PV}$ and lipid in treated and $\mathrm{scCO}_{2}$-treated shrimps, but $\mathrm{scCO}_{2}$ treatment significantly affected $\mathrm{pH}$, TVBN, and microbial count during storage. The initial TVB$\mathrm{N}$ value of untreated and treated shrimps was 9.33 and $9.95 \mathrm{mg} / 100 \mathrm{~g}$, respectively. The TVB-N scales of acceptability for raw shrimps are $<12 \mathrm{mg} \mathrm{N} / 100 \mathrm{~g}$ for fresh, 12-20 for edible but slightly decomposed, 20-25 for borderline, and $>25 \mathrm{mg} \mathrm{N} / 100 \mathrm{~g}$ for inedible and decomposed [7]. All shrimps showed an increase of TVB-N during 10 days of storage. It sharply increased in fresh shrimp and reached $32.59 \mathrm{mg} / 100 \mathrm{~g}$ at day 10 of storage, whereas it flatly increased in treated shrimps with $\mathrm{scCO}_{2}$ and ended at $30.21 \mathrm{mg} / 100 \mathrm{~g}$ at day 10 of storage. Our results indicated that the TVB-N $(24.21 \mathrm{mg} / \mathrm{g})$ of treated shrimps with $\mathrm{scCO}_{2}$ was not acceptable after day 8 of storage. Most likely, the spoilage of shrimp was caused by degradation of nitrogenous compounds as a result of the activity of endogenous enzymes [41].

Figure 5 shows that the initial microbiological count of fresh and treated shrimp was $4.4 \times 10^{5}$ and $3.9 \times 10^{4} \mathrm{CFU} / \mathrm{g}$, respectively. For treated shrimps, the microbiological count started to increase at day 4 and flatly grew until at day 10 of storage $\left(5.1 \times 10^{6} \mathrm{CFU} / \mathrm{g}\right)$. The increased counts were likely associated with the adaptability of the bacteria, which were resistant and adaptable to refrigeration temperature. Some aerobic mesophilic bacteria, including spore producing bacteria, may be present in the treated shrimps. Even though psychrotrophs are able to grow at refrigeration temperature [42], these bacteria are easily destroyed by HPCD treatment [43].

The change of $\mathrm{pH}$ in shrimp meat could be one of the indications of its freshness during storage [2]. The initial $\mathrm{pH}$ value of treated shrimps was 7.7 and gradually declined to 6.6 and was flat after day 6 of storage (Figure 6). Jin et al. [44] found that the initial $\mathrm{pH}$ of marine-trawling shrimps was 7.02, and no significant differences were found during deepfrozen temperature storage. Dai et al. [45] reported that the decrease in $\mathrm{pH}$ could result from glycogen glycolysis of shrimp for an hour after death, while the increase in $\mathrm{pH}$ is related to the accumulation of alkaline molecules, such as ammonia and amines, produced from the metabolism of amino acids, peptides, and protein. In this present study, the decline of the $\mathrm{pH}$ value suggested that the $\mathrm{scCO}_{2}$ treatment could have an inhibitory effect that slows down the $\mathrm{pH}$ of the shrimps during storage. New macromolecule conformations as a result of protein denaturation and ionic formation of $\mathrm{HCO}_{3}{ }^{-}$and $\mathrm{CO}_{3}{ }^{-}$in the matrix of shrimp meat due to diffusivity of $\mathrm{CO}_{2}$ treatment could influence $\mathrm{pH}$ changes during storage at $4^{\circ} \mathrm{C}$. Moreover, there is no protein buffering effect in this case because the denaturation or conformation of the unfolded protein as a result of the $\mathrm{scCO}_{2}$ treatment changes its function. In general, $\mathrm{pH} 7.7$ or below is the scope for good freshness of the shrimps [46]. Illera et al. [6] reported that $\mathrm{HPCD}$ treatment at $12 \mathrm{MPa}, 40^{\circ} \mathrm{C}$ deactivated $\mathrm{PPO}$ in shrimps and produced good visual aspects for 5 days of storage at $4^{\circ} \mathrm{C}$.

Sensory analysis of treated and untreated shrimps during storage at $4^{\circ} \mathrm{C}$ included Duo-Trio test and Hedonic test. Duo-Trio test was where sensory panelists were asked to distinguish the sample that had slight differences in aroma, color, and texture (Table 6). Twenty panelists were involved. So, there must be 18 panelists stating that the sample differs from the standard sample at the $5 \%$ level. It was shown that sensory panelists did not recognize odor differences between $\mathrm{scCO}_{2}$-treated shrimps and untreated shrimps during the storage. All of the 20 sensory panelists stated that the $\mathrm{ScCO}_{2}$ treated sample (code 983) had a significant difference in terms of color compared with the other samples at eight-day storage, while 16 sensory panelists stated that the untreated sample (code 611) had a texture different from that of the 
TABLE 5: Recapitulation of quality parameter values in white shrimp (Litopenaeus vannamei) treated with high-pressure $\mathrm{CO}_{2}$.

\begin{tabular}{|c|c|c|c|c|c|c|c|c|c|c|}
\hline \multirow{2}{*}{ Quality parameter } & \multicolumn{10}{|c|}{ Treatment (pressure $(\mathrm{psi}) /$ holding time $(\min ))$} \\
\hline & $900 / 5$ & $900 / 10$ & $900 / 15$ & $950 / 5$ & $950 / 10$ & $950 / 15$ & $1100 / 5$ & $1100 / 10$ & $1100 / 15$ & Untreated \\
\hline Moisture (\%) & 79.99 & 79.84 & 79.97 & 77.21 & 78.48 & 78.29 & 77.9 & $74.96^{*}$ & $74.38^{*}$ & 79.08 \\
\hline Fat $(\%)$ & 0.35 & 0.38 & 0.28 & 0.275 & 0.235 & $0.6^{*}$ & 0.77 & $0.78^{*}$ & 0.77 & 0.28 \\
\hline Protein $(\%)$ & $16.04^{*}$ & 18.11 & $16.75^{*}$ & 18.21 & $18.15^{*}$ & $16.78^{*}$ & 18.45 & 18.94 & 18.21 & 18,09 \\
\hline Hardness $\left(\mathrm{kN} / \mathrm{m}^{2}\right)$ & 79.8 & 58.3 & 27.9 & $74.6^{*}$ & $69.9^{*}$ & 62 & 62.4 & 55.2 & 57.6 & 46.1 \\
\hline$\Delta \mathrm{L}^{*}$ value & 51.65 & 54.15 & 59.1 & 53.75 & 52.05 & 54.9 & 59.75 & 56.75 & $61.35^{*}$ & 51.55 \\
\hline$a^{*}$ value & 5.55 & 5.15 & 5.25 & 5 & 4.05 & 5.6 & 5.25 & $5.85^{*}$ & 7.1 & 4.15 \\
\hline Cholesterol (mg/g) & $1.39^{*}$ & 1.27 & 1.46 & 1.47 & 1.39 & $1.36^{*}$ & 1.46 & $1.48^{*}$ & $1.34^{*}$ & 1.63 \\
\hline Total carotene $(\mathrm{mg} / \mathrm{g})$ & 3.8 & 3.78 & 3.79 & 3.77 & 3.76 & 3.69 & 2.51 & $2.37^{*}$ & $2.29^{*}$ & 4.24 \\
\hline Microbial reduction $(\log \mathrm{N} / \mathrm{No})$ & 0.98 & 0.979 & 0.974 & 0.974 & 0.969 & 0.952 & 0.803 & 0.805 & 0.793 & \\
\hline
\end{tabular}

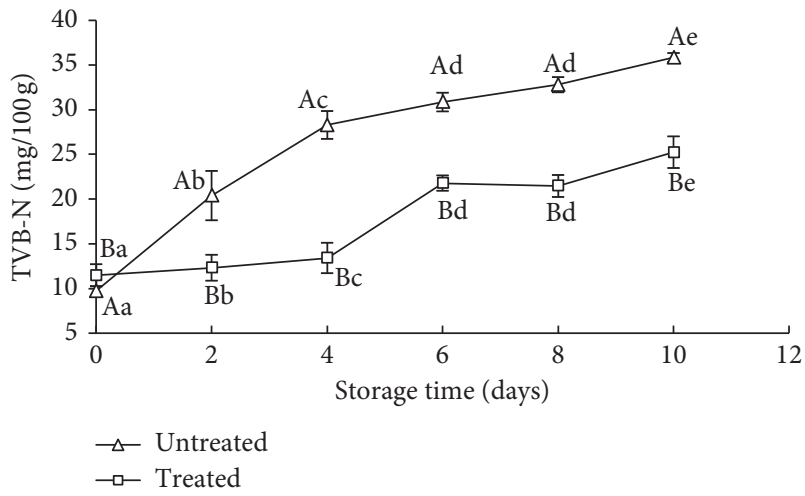

FIGURE 4: Changes of TVB-N during storage of untreated and $\mathrm{scCO}_{2}$-treated shrimp at $4^{\circ} \mathrm{C}$ for 10 days. Different capital letters indicate that the treatment had significant effect on TVB-N value $(p<0.05)$. The different lowercase letters indicate that storage time had a significant effect on TVN value $(p<0.05)$.

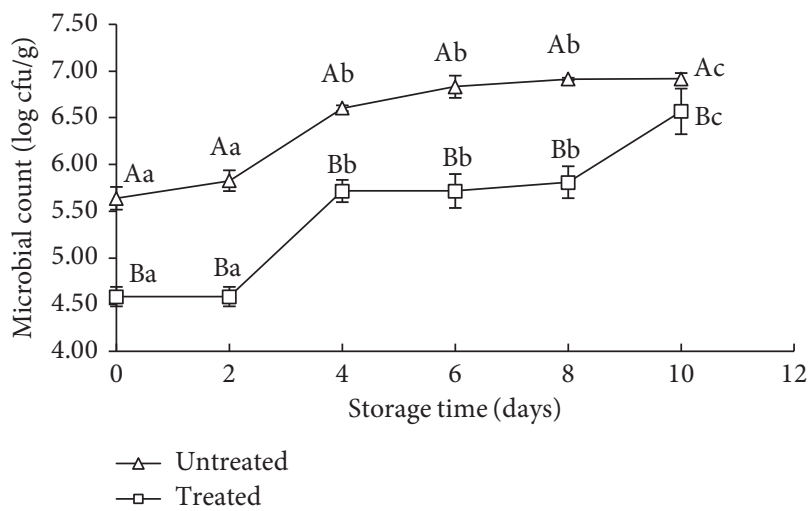

Figure 5: Changes of microbial count during storage of untreated and $\mathrm{scCO}_{2}$-treated shrimps at $4^{\circ} \mathrm{C}$ for 10 days. Different capital letters indicate that the treatment had significant effect on microbial count $(p<0.05)$. The different lowercase letters indicate that storage time had significant effect on microbial count $(p<0.05)$

other samples at day 6 of storage. Similarly, Kincal et al. [47] showed that the sensory panelists could not detect any significant aroma differences between the control frozen fresh orange juice and HPCD-treated orange juice after a two-week storage at $17^{\circ} \mathrm{C}$. Some researchers showed that
HPCD slightly reduced volatile compounds [48, 49]. Chen et al. [48] found no change in ester composition and slight change in alcohol and aldehydes in Hami melon juice after treatment with HPCD at $35 \mathrm{MPa}$ and $55^{\circ} \mathrm{C}$ for $60 \mathrm{~min}$ and four-week storage. Zhou et al. [50] found that low threshold was responsible for the changes in the odor/flavor of foods. The aroma of foods mostly generated from volatile compounds. In shrimps, volatile compounds can be come from chemical reactions and enzymatic reactions, involving amino acids side chain of protein, carbohydrate, and lipid. When $\mathrm{scCO}_{2}$ was used, lipid and nonpolar amino acids were oxidized or extracted, enzymatic activation was changed, and new volatile compounds in the food matrix can be produced. However, the volatile compound may be stripped off during depressurized $\mathrm{CO}_{2}$, thereby having no effect on food odor. This was why the sensory panelists could not differentiate between the treated and untreated shrimps. Kleekayai et al. [51] found that $\mathrm{N}$ - and S-containing compounds with major volatile compounds, trimethylamine, 2,5-dimethylpyrazine, and dimethyl trisulfide, and nonpolar compounds were responsible for the aroma of shrimps. In addition, aldehydes, ketones, and alcohols mostly produced from oxidative cleavages of lipids, and degradation of amino acids and saccharides were also responsible for the shrimp odor.

Consumer acceptance test was performed by 20 students from the departments. A 5-point hedonic scale was used to evaluate overall acceptance and color, texture, and odor acceptance (Figure 9). Any changes in the compounds responsible for the color, texture, and odor can lead to their acceptance. It can be concluded that, among the samples, there was no hedonic difference in odor, color, and texture, as well as overall acceptance $(p<0.05)$. The score of overall acceptance was moderate (score of 3.8) for treated shrimp at eight-day storage. Sensory panelist acceptance to the sense of color was moderate (score of 3.8) for treated shrimp at eightday storage. However, acceptance of sensory panelists to odor was neither like or dislike (score of 3.0) for treated shrimp during storage at $4^{\circ} \mathrm{C}$. The score of the sense of texture given by sensory panelists was neither like or dislike (3.1) during storage at $4^{\circ} \mathrm{C}$, but panelists accepted the sample more (score of 3.8 , moderate) at eight-day storage.

Figure 7 shows the lipid changes of $\mathrm{scCO}_{2}$-treated and untreated shrimps during storage. The result of analysis variance showed that both the $\mathrm{scCO}_{2}$ treatment and storage 


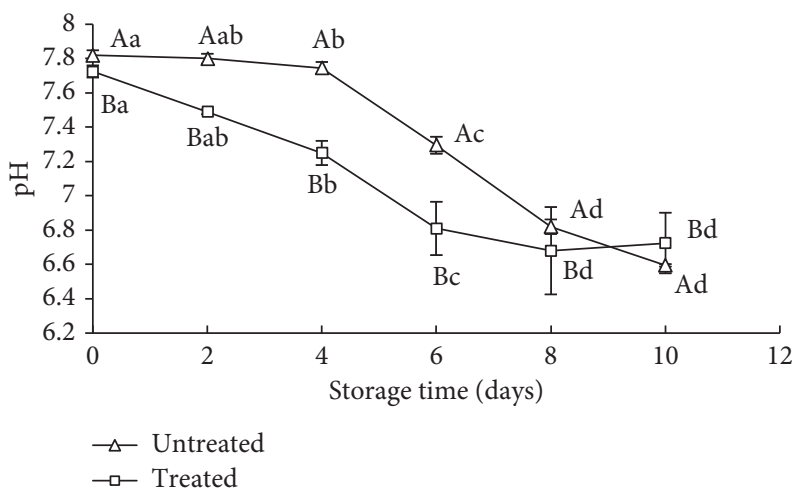

Figure 6: Changes of $\mathrm{pH}$ during storage of untreated and $\mathrm{scCO}_{2}$-treated shrimps at $4^{\circ} \mathrm{C}$ for 10 days. Different capital letters indicate that the treatment had significant effect on $\mathrm{pH}$ value $(p<0.05)$. The different lowercase letters indicate that storage time had significant effect on $\mathrm{pH}$ value $(p<0.05)$.

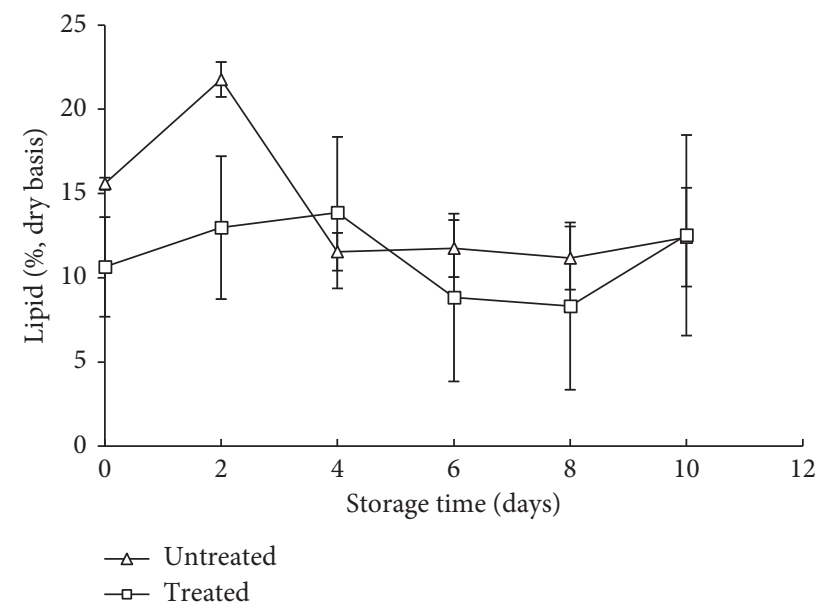

FIgURE 7: Changes of total lipid during storage of untreated and $\mathrm{scCO}_{2}$-treated shrimps at $4^{\circ} \mathrm{C}$ for 10 days.

time did not significantly affect the total lipid during storage $(p>0.05)$. The same results were reported by Senapati et al. [52], which showed that the crude fat content of white-leg shrimps (Litopenaeus vannamei) did not significantly change during 14 days of chilled storage. In this study, supercritical $\mathrm{CO}_{2}$ treatment and low storage temperature could protect shrimp fat from hydrolysis; therefore, no significant fat changes were found during storage at $4^{\circ} \mathrm{C}$. Shrimp lipids, a nonpolar biomolecule, are reduced when the shrimp is treated with $\mathrm{scCO}_{2}$, thereby preventing possible hydrolysis during storage. Supercritical $\mathrm{CO}_{2}$ dissolves nonpolar or slightly polar compounds [4]. Additionally, lipid hydrolysis occurred rapidly at higher storage temperatures, which increased free fatty acids, resulting in the shrimps' off odor [53, 54].

Figure 8 shows the peroxide value (PV) changes in $\mathrm{scCO}_{2}$-treated and untreated shrimps during storage. The result of analysis of variance showed that $\mathrm{scCO}_{2}$ treatment and storage time did not significantly affect the PV during storage $(p>0.05)$. Similar results were reported by Minh et al. [55] that showed that the PV of black tiger shrimp (Penaeus monodon) control samples did not significantly change during 12 months of storage. In this study, $\mathrm{scCO}_{2}$ treatment could potentially slow down the mechanisms responsible for lipid damage in shrimps during storage at $4^{\circ} \mathrm{C}$. Peroxide value is a product of lipid autoxidation, which indicates the oxidation deterioration level of lipid. Lipid deterioration is influenced by the oxygen presence, temperature, and light during the storage of product [56-58]. Additionally, temperature affected PV value, which significantly increased when shrimps were kept under high temperature and in the presence of sunlight [59].Light catalyzes the oxidation of lipid under photo-oxidation process. During photo-oxidation, the energy of light is absorbed and turns the free radical group, triplet oxygen into singlet oxygen, which easily reacts with unsaturated fatty acids and generates hydrogen peroxide [60].

It could be said that $\mathrm{scCO}_{2}$-treated shrimps were accepted by panelists until eight-day storage at $4{ }^{\circ} \mathrm{C}$ and found no significant changes in quality degradation parameters responsible for shrimp deterioration. 


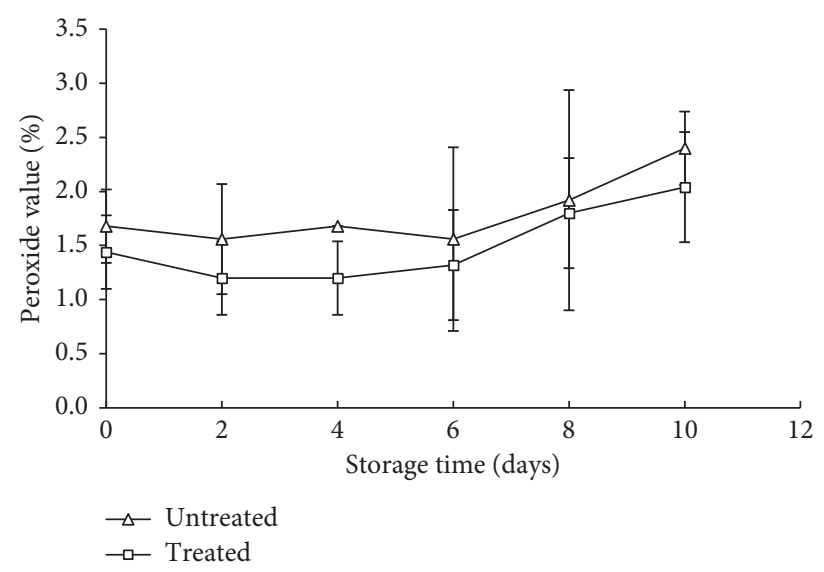

Figure 8: Changes of peroxide value during storage of untreated and $\mathrm{scCO}_{2}$-treated shrimps at $4^{\circ} \mathrm{C}$ for 10 days.

TABLE 6: Duo-Trio test of untreated and treated shrimps with supercritical $\mathrm{CO}_{2}$ during storage at $4^{\circ} \mathrm{C}$.

\begin{tabular}{lcccccccccccc}
\hline \multirow{2}{*}{ Parameters } & \multicolumn{2}{c}{ Day 0 } & \multicolumn{2}{c}{ Day 2 } & \multicolumn{2}{c}{ Day 4} & \multicolumn{2}{c}{ Day 6} & \multicolumn{2}{c}{ Day 8} & \multicolumn{2}{c}{ Day 10} \\
& 463 & 198 & 257 & 671 & 553 & 879 & 611 & 537 & 227 & 983 & 265 & 871 \\
\hline Odor & 13 & 10 & 10 & 13 & 12 & 11 & 10 & 13 & 11 & 12 & 12 \\
Color & 10 & 13 & 10 & 13 & 9 & 14 & 15 & 8 & 3 & $20^{*}$ & 11 \\
Texture & 15 & 8 & 11 & 12 & 13 & 10 & $16^{*}$ & 7 & 15 & 8 & 13 & 12 \\
\hline
\end{tabular}

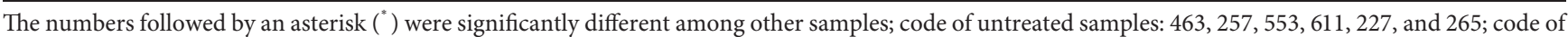
samples treated with supercritical $\mathrm{CO}_{2}: 198,671,879,537,983$, and 871 .

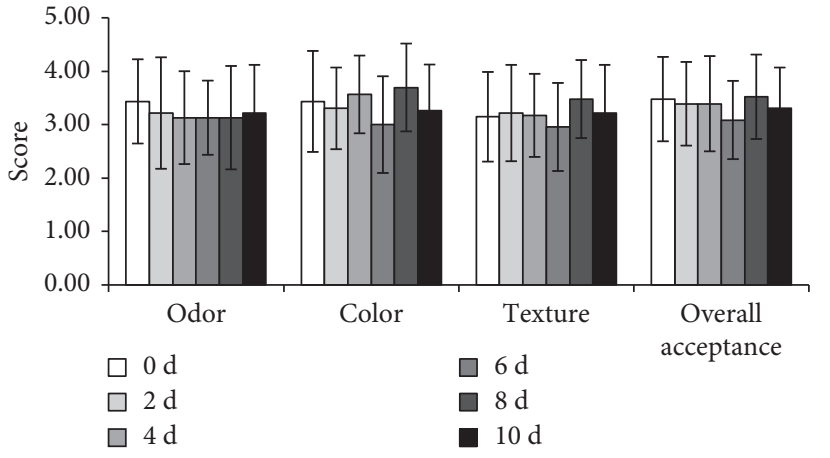

Figure 9: Consumer acceptance test of $\mathrm{scCO}_{2}$-treated shrimps during storage at $4^{\circ} \mathrm{C}$ by using a 5 -point hedonic scale.

\section{Conclusions}

Subcritical and supercritical $\mathrm{CO}_{2}$ did not affect the hardness and lightness of shrimps, indicating that the quality of freshness of shrimps is maintained. However, cholesterol reduction occurred at either the subcritical or supercritical treatment. Supercritical $\mathrm{CO}_{2}$ treatment at 1100 psi for $10 \mathrm{~min}$ was the best treatment recommended for processing white shrimps. A storage study was performed to see the effectiveness of $\mathrm{scCO}_{2}$ treatment at 1100 psi for 10 min during storage. No significant changes were found in $\mathrm{PV}$ and lipid in untreated and $\mathrm{scCO}_{2}$-treated shrimps, but the treatment significantly affected $\mathrm{pH}$, TVBN, and microbial counts during storage. Among the samples, there was no hedonic difference in odor, color, texture, and overall acceptance during storage. Moreover, untreated shrimps possessed a texture significantly different from that of the other samples at six-day storage, while $\mathrm{scCO}_{2}$-treated shrimps possessed a very significant color difference compared with the other samples at eightday storage.

It was found that $\mathrm{scCO}_{2}$-treated shrimps, at $1100 \mathrm{psi}$ for $10 \mathrm{~min}$, were accepted by panelists when stored up to eight days. The results of this study provided useful information about the possibility of applying supercritical $\mathrm{CO}_{2}$ at 1100 psi for $10 \mathrm{~min}$ as an alternative method for preservation of shrimps.

\section{Data Availability}

All data generated or analyzed during this study are included within the article.

\section{Conflicts of Interest}

The authors declare that there are no conflicts of interest

\section{Acknowledgments}

The authors greatly thank Prof. Dr. Irwan Sukri Banuwa, the Dean of the Faculty of Agriculture, University of Lampung, and Prof. Daniel Saputra, PhD at the University of Sriwijaya, Palembang, Indonesia. This project was supported by the Ministry of Research and Technology-National Research and Innovation Agency (RISTEK-BRIN) (contract nos. 4375/UN26.21/PN/2020 and 179/SP2H/AMD/LT/DRPM/ 2020). 


\section{References}

[1] K. Manheem, S. Benjakul, K. Kijroongrojana, N. Faithong, and W. Visessanguan, "Effect of pre-cooking times on enzymes, properties, and melanosis of Pacific white shrimp during refrigerated storage," International Aquatic Research, vol. 5, no. 1, pp. 1-11, 2013.

[2] N. Xu, W. Shi, X. Wang, and Z. Wang, "Effect of ice water pretreatment on the quality of Pacific White Shrimps ( Litopenaeus vannamei )," Food Science \& Nutrition, vol. 7, no. 2, pp. 645-655, 2019.

[3] L. Laboureur, M. Ollero, and D. Touboul, "Lipidomics by supercritical fluid chromatography," International Journal of Molecular Sciences, vol. 16, no. 12, pp. 13868-13884, 2015.

[4] H. Monhemi and S. Dolatabadi, "Molecular dynamics simulation of high-pressure $\mathrm{CO}_{2}$ pasteurization reveals the interfacial denaturation of proteins at $\mathrm{CO}_{2}$ /water interface," Journal of CO2 Utilization, vol. 35, pp. 256-264, 2020.

[5] I. Higuera-Ciapara, A. R. Toledo-Guillen, L. Noriega-Orozco, K. G. Martinez-Robinson, and M. C. Esquade-Valle, "Prodution of a low-cholesterol shrimp using supercritical extraction," Journal of Food Process Engineering, vol. 28, no. 5, pp. 526-538, 2005.

[6] A. E. Illera, M. T. Sanz, S. Beltrán, and O. Benito-Román, "Effect of high pressure carbon dioxide on polyphenoloxidase from Litopenaeus vannamei," LWT, vol. 109, pp. 359-365, 2019.

[7] B. Zhang, L. K. Ma, S. G. Deng, C. Xie, and X. H. Qiu, "Shelflife of pacific white shrimp (Litopenaeus vannamei) as affected by weakly acidic electrolyzed water ice-glazing and modified atmosphere packaging," Food Control, vol. 51, pp. 114-121, 2015.

[8] J. Li, W. Sun, H. S. Ramaswamy et al., "High pressure extraction of astaxanthin from shrimp waste (Penaeus Vannamei Boone): effect on yield and antioxidant activity," Journal of Food Process Engineering, vol. 40, no. 2, p. e12353, 2017.

[9] T. Jantakoson, K. Kijroongrojana, and S. Benjakul, "Effect of high pressure and heat treatments on black tiger shrimp (Penaeus monodon Fabricius) muscle protein," International Aquatic Research, vol. 4, no. 1, pp. 1-12, 2012.

[10] M. McHugh and V. Krukonis, Supercritical Fluid Extraction, H. Brenner, Ed., Butterworth-Heinemann, UK, 2nd edition, 2013.

[11] B. Werner and J. Hotchkiss, "Modified atmosphere packaging," in Microbiology of Fruits and Vegetables, M. G. Sapers, J. R. Gorny, and A. E. Yousef, Eds., CRC Press, Boca Raton, FL, USA, 1st edition, 2006.

[12] D. Saputra, "Puffing dehydrated vegetable with carbon dioxide," in Jurnal Keteknikan Pertanian, pp. 157-165, 2006.

[13] M. Plascencia-Jatomea, G. Viniegra, R. Olayo, M. M. CastilloOrtega, and K. Shirai, "Effect of chitosan and temperature on spore germination of Aspergillus Niger," Macromolecular Bioscience, vol. 3, no. 10, pp. 582-586, 2003.

[14] T. Saldanha, M. T. Benassi, and N. Bragagnolo, "Fatty acid contents evolution and cholesterol oxides formation in Brazilian sardines (Sardinella brasiliensis) as a result of frozen storage followed by grilling," LWT-Food Science and Technology, vol. 41, no. 7, pp. 1301-1309, 2008.

[15] H. D. de Holanda and F. M. Netto, "Recovery of components from shrimp (Xiphopenaeus kroyeri) processing waste by enzymatic hydrolysis," Journal of Food Science, vol. 71, no. 5, pp. C298-C303, 2006.
[16] G. Latimer, Official Methods of Analysis of AOAC International, AOAC International, Rockville, MD, USA, 21st edition, 2019.

[17] National Standardization Body, SNI 2354.8-2009: Chemical Test Method-Part 8: Determination of Total Volatile Base Nitrogen (TVB-N) and Trimethyl Amin Nitrogen (TMA-N) Levels in Fishery Products, National Standardization Body, Geneva, Switzerland, 2009.

[18] IFRA, Determination of the Peroxide Value, The International Fragrance Association, Geneva, Switzerland, 2019.

[19] J. A. Dorado-Rodelo, J. M. Ezquerra-Brauer, and H. SotoValdez, "Effect of ovenproof plastic films on the quality of spotted rose snapper (Lutjanus guttatus) fillets during frozen storage," Packaging Technology and Science, vol. 20, no. 5, pp. 301-307, 2007.

[20] M. Meilgaard, G. V. Civille, and B. T. Carr, Sensory Evaluation Techniques, CRC Press, Boca Raton, FL, USA, 4th edition, 2007.

[21] H. S. Youn, M. K. Roh, A. Weber, G. T. Wilkinson, and B. S. Chun, "Solubility of astaxanthin in supercritical carbon dioxide," Korean Journal of Chemical Engineering, vol. 24, no. 5, pp. 831-834, 2007.

[22] A. P. Sánchez-Camargo, H. A. Martinez-Correa, L. C. Paviani, and F. A. Cabral, "Supercritical $\mathrm{CO}_{2}$ extraction of lipids and astaxanthin from Brazilian redspotted shrimp waste (Farfantepenaeus paulensis)," Journal of Supercritical Fluids, vol. 56, no. 2, pp. 164-173, 2011.

[23] F. J. Pashkow, D. G. Watumull, and C. L. Campbell, "Astaxanthin: a novel potential treatment for oxidative stress and inflammation in cardiovascular disease," American Journal of Cardiology, vol. 101, no. 10 Suppl, pp. S58-S68, 2008.

[24] J. Li, C. Guo, and J. Wu, "Astaxanthin in liver health and disease: a potential therapeutic agent," Drug Design, Development and Therapy, vol. 14, pp. 2275-2285, 2020.

[25] W. Yan, J. Cui, R. Dai, H. Wang, and X. Li, "Effects of dense phase carbon dioxide on quality and physical-chemical properties of chilled pork," Nongye Gongcheng Xuebao/ Transactions of the Chinese Society of Agricultural Engineering, vol. 26, no. 7, pp. 346-350, 2010.

[26] N. S. Tabitha and T. Anand, "Nutritive value of cultured white leg shrimp Litopenaeus vannamei," International Journal of Fisheries and Aquaculture, vol. 5, no. 7, pp. 166-171, 2013.

[27] V. Venugopal, "Nutritional value of shrimp the popular shellfish," EC Nutrition, vol. 02, pp. 1-9, 2020.

[28] C. Da Porto and A. Natolino, "Supercritical fluid extraction of polyphenols from grape seed (Vitis vinifera): study on process variables and kinetics," Journal of Supercritical Fluids, vol. 130, pp. 239-245, 2017.

[29] S. Sugiharto, N. Bintoro, J. Karyadi, and Y. Pranoto, "Supercritical carbon dioxide pasteurization to reduce the activity of muscle protease and its impact on physicochemical properties of Nile tilapia," Research Ideas and Outcomes, vol. 6, p. $56887,2020$.

[30] M. E. Kustyawati, F. Pratama, D. Saputra, and A. Wijaya, "Viability of molds and bacteria in tempeh processed with supercritical carbon dioxides during storage," International Journal of Food Science, vol. 2018, 2018.

[31] O. Erkmen, "Antimicrobial effects of pressurised carbon dioxide on Brochothrix thermosphacta in broth and foods," Journal of the Science of Food and Agriculture, vol. 80, no. 9, pp. 1365-1370, 2000.

[32] D. R. Pires, D. Morais, A. C. N. Coelho, A. F. Góes, L. C. D. S. A. Ferreira, and T. Saldanha, "Nutritional 
composition, fatty acids and cholesterol levels in Atlantic white shrimp (Litopenaeus schimitti)," International Food Research Journal, vol. 25, no. 1, pp. 151-157, 2018.

[33] S. M. Pourmortazavi, Z. Saghafi, A. Ehsani, and M. Yousefi, "Application of supercritical fluids in cholesterol extraction from foodstuffs: a review," Journal of Food Science and Technology, vol. 55, no. 8, pp. 2813-2823, 2018.

[34] O. H. Nautiyal, "Review article food processing by supercritical carbon dioxide-review," EC Chemistry, vol. 2, no. 1, pp. 111-135, 2016.

[35] D. Kartono, J. A. B. Hardiyansyah, and A. Sulaeman, "Summary of recommended nutritional adequacy for Indonesians," in Proceedings of the Widyakarya Nasional Pangan Dan Gizi (WNPG) X, pp. 1-18, Jakarta, Indonesia, April 2017.

[36] R. K. Eldiaz, A. Agustono, and K. T. Pursetyo, "The content of low density lipoprotein, high density lipoproteins, cholesterol on pen shells (Atrina pectinata) fish catch in kenjeran surabaya," Journal of Marine and Coastal Science, vol. 7, no. 2, p. 51, 2020.

[37] N. Mezzomo and S. R. S. Ferreira, "Carotenoids functionality, sources, and processing by supercritical technology: a review," Journal of Chemistry, vol. 2016, Article ID 3164312, 17 pages, 2016.

[38] S. A. Radzali, B. S. Baharin, and R. A. Rahman, "Optimisation of supercritical fluid extraction of astaxanthin from Penaeus monodon waste using ethanol-modified carbon dioxide," Journal of Engineering Science and Technology, vol. 11, no. 5, pp. 722-736, 2016.

[39] K. Marszałek, Ł. Woźniak, B. Kruszewski, and S. Skapska, "The effect of high pressure techniques on the stability of anthocyanins in fruit and vegetables," International Journal of Molecular Sciences, vol. 18, no. 2, 2017.

[40] A. Molino, V. Larocca, G. Di Sanzo et al., "Extraction of bioactive compounds using supercritical carbon dioxide," Molecules, vol. 24, no. 4, 2019.

[41] C. Niamnuy, S. Devahastin, and S. Soponronnarit, "Quality changes of shrimp during boiling in salt solution," Journal of Food Science, vol. 72, no. 5, pp. S289-S297, 2007.

[42] J. M. Jay, M. J. Loessner, and D. A. Golden, Modern Food Microbiology, Springer US, New York, NY, USA, 7th edition, 2005.

[43] T. Yu, L. Niu, and H. Iwahashi, "High-pressure carbon dioxide used for pasteurization in food industry," in Food Engineering Reviews, vol. 12, no. 3, pp. 364-380, 2020.

[44] L. Jin, G. Ding, P. Li, J. Gu, and X. Zhang, "Changes in quality attributes of marine-trawling shrimp (Solenocera crassicornis) during storage under different deep-frozen temperatures," Journal of Food Science and Technology, vol. 55, no. 8, pp. 2890-2898, 2018.

[45] X. Y. Dai, M. X. Zhang, X. Y. Wei, R. C. Hider, and T. Zhou, "Novel multifunctional hydroxypyridinone derivatives as potential shrimp preservatives," Food and Bioprocess Technology, vol. 9, no. 7, pp. 1079-1088, 2016.

[46] H. Mu, H. Chen, X. Fang, J. Mao, and H. Gao, "Effect of cinnamaldehyde on melanosis and spoilage of Pacific white shrimp (Litopenaeus vannamei) during storage," Journal of the Science of Food and Agriculture, vol. 92, no. 10, pp. 2177-2182, 2012.

[47] D. Kincal, W. S. Hill, M. Balaban et al., "A continuous highpressure carbon dioxide system for cloud and quality retention in orange juice," Journal of Food Science, vol. 71, no. 6, pp. C338-C344, 2006.

[48] J. L. Chen, J. Zhang, L. Song, Y. Jiang, J. Wu, and X. S. Hu, "Changes in microorganism, enzyme, aroma of hami melon
(Cucumis melo L.) juice treated with dense phase carbon dioxide and stored at $4^{\circ} \mathrm{C}$," Innovative Food Science and Emerging Technologies, vol. 11, no. 4, pp. 623-629, 2010.

[49] L. Niu, X. Hu, J. Wu et al., "Effect of dense phase carbon dioxide process on physicochemical properties and flavor compounds of orange juice," Journal of Food Processing and Preservation, vol. 34, no. Suppl. 2, pp. 530-548, 2010.

[50] L. Zhou, X. Bi, Z. Xu, Y. Yang, and X. Liao, "Effects of highpressure $\mathrm{CO}_{2}$ processing on flavor, texture, and color of foods," Critical Reviews in Food Science and Nutrition, vol. 55, no. 6, pp. 750-768, 2015.

[51] T. Kleekayai, S. Pinitklang, N. Laohakunjit, and W. Suntornsuk, "Volatile components and sensory characteristics of Thai traditional fermented shrimp pastes during fermentation periods," Journal of Food Science and Technology, vol. 53, no. 3, pp. 1399-1410, 2016.

[52] S. R. Senapati, G. P. Kumar, C. B. Singh et al., "Melanosis and quality attributes of chill stored farm raised whiteleg shrimp (Litopenaeus vannamei)," Journal of Applied and Natural Science, vol. 9, no. 1, pp. 626-631, 2017.

[53] J. Lu, M. Langton, S. Sampels, and J. Pickova, "Lipolysis and oxidation in ultra-high temperature milk depend on sampling month, storage duration, and temperature," Journal of Food Science, vol. 84, no. 5, pp. 1045-1053, 2019.

[54] C. Rivera-Pérez, F. L. García-Carreño, and R. Saborowski, "Purification and biochemical characterization of digestive lipase in whiteleg shrimp," Marine Biotechnology, vol. 13, no. 2, pp. 284-295, 2011.

[55] N. P. Minh, T. Thi, Y. Nhi et al., "Quality of frozen black tiger shrimp (Penaeus monodon) under a low-density polyethylene bag coextruded with butylated hydroxyanisole," vol. 11, no. 4, pp. 1483-1486, 2019.

[56] M. H. Gordon, "Factors affecting lipid oxidation," in Understanding and Measuring the Shelf-Life of Food, Woodhead Publishing Limited, Sawston, UK, 2004.

[57] D. R. Johnson and E. A. Decker, "The role of oxygen in lipid oxidation reactions: a review," Annual Review of Food Science and Technology, vol. 6, pp. 171-190, 2015.

[58] F. Kong and R. P. Singh, "Advances in instrumental methods to determine food quality deterioration," in Food and Beverage Stability and Shelf Life, Woodhead Publishing Limited, Sawston, UK, 2011.

[59] D. Y. Li, Z. Yuan, Z. Q. Liu et al., "Effect of oxidation and maillard reaction on color deterioration of ready-to-eat shrimps during storage," Lwt, vol. 131, Article ID 109696, 2020.

[60] H. H. Chang, Quantitative Changes of Volatile Compound in Soybean and Algal Oil and Effects of Antioxidants on the Oxidative Stability of Algal Oil under Light Storage, The Ohio State University, Columbus, OH, USA, 2011. 